\title{
11
}

\section{Land and sea animal remains from Middle Neolithic Pitted Ware sites on Gotland Island in the Baltic Sea, Sweden}

\author{
Helene Martinsson-Wallin \\ Department of Archaeology and Osteology, Gotland University, Sweden \\ Helene.Martinsson-Wallin@hgo.se
}

\section{Introduction}

Prehistoric bone material from Gotland Island situated in the centre of the Baltic Sea (Figure 1) is remarkably well preserved due to the island's limestone substrate. Archaeological research and excavation has been ongoing on the island since the beginning of last century (Wennersten 1907; Nihlén 1927; Stenberger et al. 1943), and the use of traditional farming methods has spared many prehistoric sites from destruction. The numerous archaeological excavations have resulted in a large and well-documented sample of human and animal bone material from Mesolithic and Neolithic sites. The bones occur both as food residue in occupation areas and as human remains in graves, which are sometimes associated with grave goods in the form of worked and unworked animal bone. In this paper, I investigate differences in the faunal assemblages recovered from five Pitted Ware sites dating to the Middle-Late Neolithic using a statistical comparison, and then examine whether the inter-site variation was caused by site chronology and environmental variability, or whether the difference might be due to cultural practices, such as the use of particular animals as symbols of group identity by Pitted Ware communities.

Background

Gotland Island formed in a tropical sea some 425 million years ago during the Silurian Era, after which the island was pushed down by the expansion of ice sheets during the Pleistocene. During the Holocene, parts of Gotland had risen above sea level by around 9000-10,000 years ago, and the island is still uplifting at a rate of $1 \mathrm{~mm} /$ year. The northern part of the island was the first to emerge above sea level from the evidence of sites such as Strå, Svalings and Gisslause (Figure 2). However, the earliest human occupation has been found in the cave Stora Förvar on the islet Stora Karlsö, just to the west of Gotland (Figure 2) (Österholm 1989; Lindqvist and 


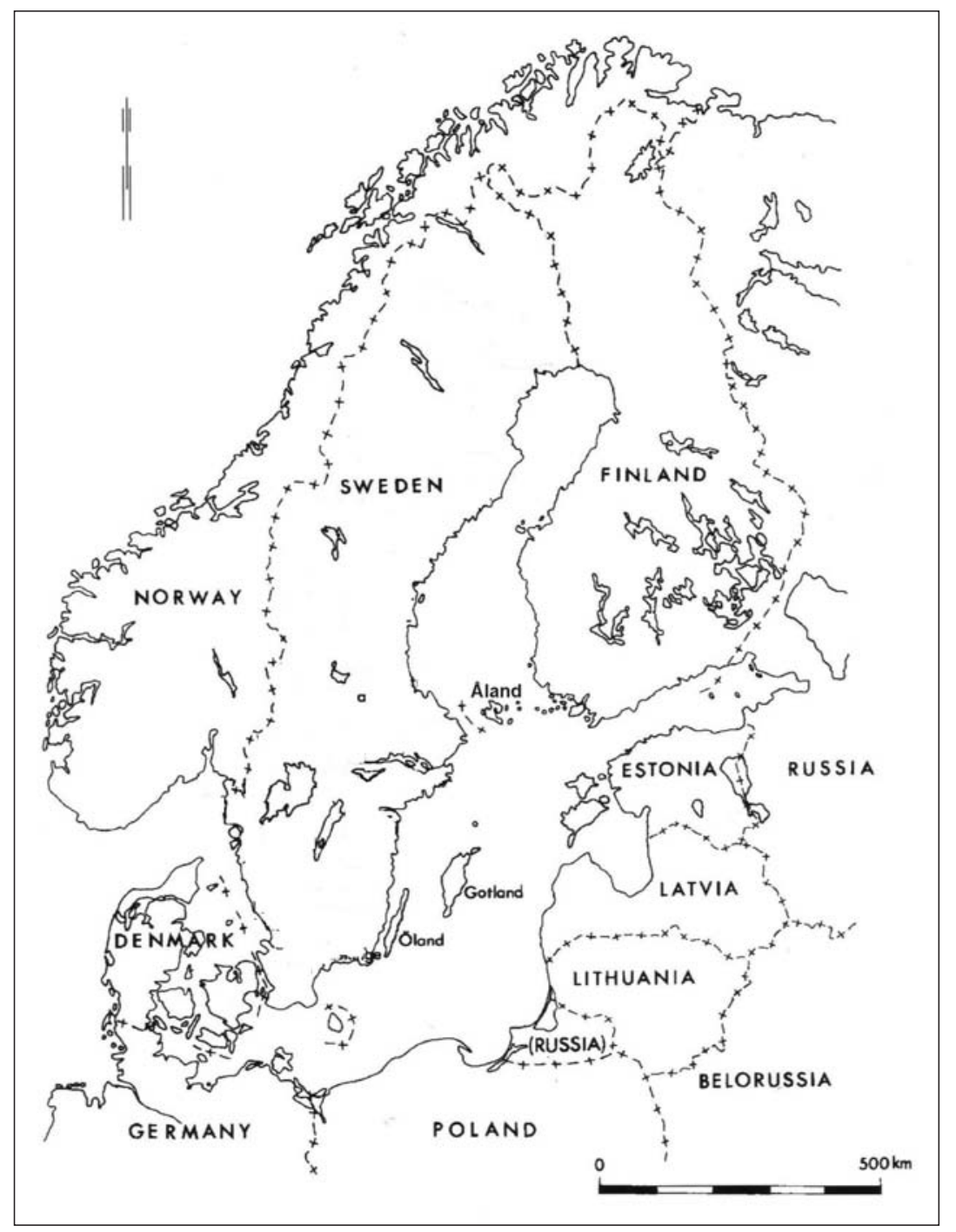

Figure 1. Map of the Baltic Sea.

Possnert 1999), which is dated to 9500-9300 BP. The early Mesolithic sites are interpreted as hunting sites from the numerous bones of seals, fish and aquatic birds (Lindqvist and Possnert 1999:81). Finds of human remains and bones of several types of seasonally available animals suggest the presence of permanent or semi-permanent camps. Seal bones are mostly of grey seal (Halichoerus grypus) and ringed seal (Phoca hispida botnica) in the Early Mesolithic phase, and of harp seal (Phoca groenlandica) and porpoise (Phocoena phocoena) in the Late Mesolithic phase (Lindqvist and Possnert 1997:29).

Before early settlement on Gotland, the Baltic Sea was cut off from the Atlantic Sea because of the uplift of areas around Denmark and North Germany - a process which turned the Baltic Sea into an inland fresh-water sea, known as the Ancylus Lake (named for the fresh-water shell Ancylus fluviatilis). The maximum transgression of the Ancylus Lake is dated to c. 10,300 BP (Svensson 1989), but by about 9200-9000 BP, it began to become more brackish, when it is termed the Mastogloia Sea after brackish water diatoms of the Mastogloia species (Lindqvist and Possnert 1997:52). The environment gradually became less brackish, and it became known as the Litorina Sea (named after the saltwater gastropod Litorina litorea), which reached its maximum by c. $7000 \mathrm{BP}$ and experienced a series of transgressions.

During the end of the milder Atlantic climate which prevailed during the Mesolithic, farming and the domestication of animals became widespread. Ideas about house building and megalith 


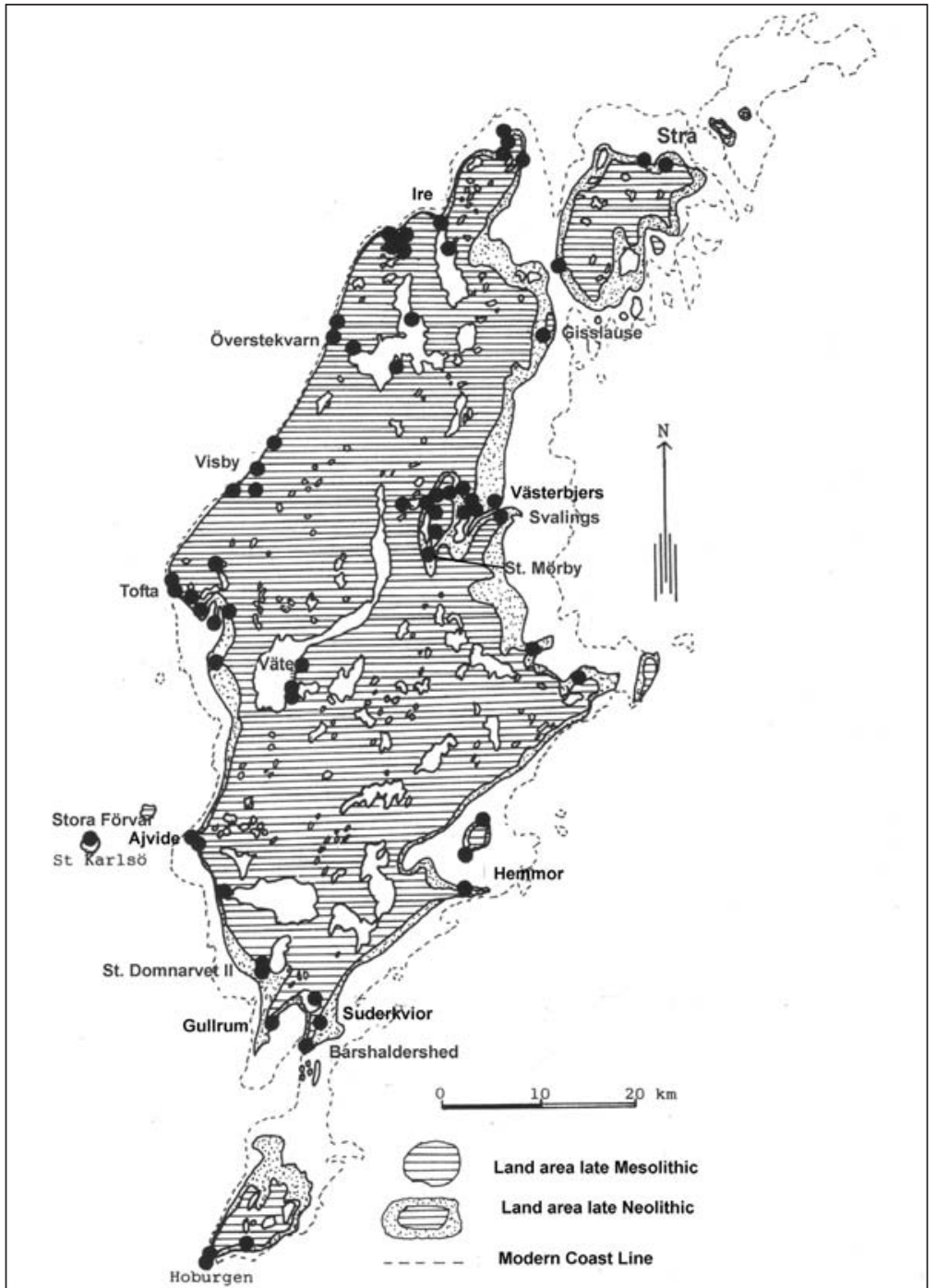

Figure 2. Map of Gotland with all known Mesolithic and Neolithic sites and site names mentioned in the text. Based on research by Österholm (1989).

graves from other parts of Europe were incorporated by pottery-using farmers in south Scandinavia (Hodder 1990). Farming and husbandry, in particular, were transmitted to Scandinavia from the continent by tribes using banded-ware ceramics, while the megalith culture had its roots in coastal Western Europe. It is postulated that the reduced saline content in the Baltic Sea during the Ancyulus and Mastogloian phases caused a decline in marine resources and the climate became colder and wetter. These conditions facilitated the uptake of farming and husbandry in south Scandinavia, a lifestyle which had long prevailed in continental Europe (Rowley-Conway 1983; Zvelebil and Rowley-Conway 1984). The shift towards a farming lifestyle is suggested by the increased use of adzes, and pollen diagrams show the clearance of inland areas suitable for farming. On Gotland, the introduction of farming activities, husbandry, and construction of megaliths occurred c. 6000-5000 years ago (Wallin and Martinsson-Wallin 1997; Österholm 1999:340). In occupation areas near to the coast, such as the Tofta area (Figure 2), a multitude of stone adzes have been found and pollen cores show large-scale land clearance (Österholm 1999:340). The construction of a megalith grave (a rectangular dolmen) has been dated to 5300-5000 BP (Lindqvist and Possnert 1997:48; Wallin and Martinsson-Wallin 1997). Finds of funnel-beaker pottery associated with megalith-building farmers have been found inland at the Mölner-Gullarve settlement (Österholm 1989:75), and at other sites including Stora Mörby, the cave site Stora Förvar, Överstekvarn I, Stora DomerarveII, Barshalderhed and Suderkvior 
(Figure 2) (Lindqvist and Possnert 1997:48). ${ }^{13} \mathrm{C}$ results from human skeletal remains from a megalith grave suggest a terrestrial or mixed terrestrial/marine diet, which contrasts with the high marine intake identified in human remains from the Mesolithic (Lindqvist and Possnert 1997:29).

During the Late Mesolithic and Early Neolithic phases the climate changed and the Baltic again became a saline sea. The return to saline conditions is likely to have had a positive effect on the productivity of the marine environment. On Gotland, this seems to have led to marine resources once again becoming the dominant source of subsistence. The emergence of substantial Pitted Ware sites in coastal locations occurred during the Middle-Late Neolithic phase, oriented toward marine subsistence, although domesticated animals such as the pig, cattle, sheep/goat and dog were utilised. Marine foods such as seals and cod were important to the diet, but domesticated or semi-domesticated pig were probably of greater social value (Rowley-Conway 1983). The Pitted Ware pots differ from the funnel-beaker ceramics in shape and decoration, and a connection between the Pitted Wares and the comb-decorated ceramics in the southeast of Scandinavia has been suggested (Wyszomirska 1984; Martinsson 1986:10; Papmehl-Dyfay 2006:37). The dominant decoration on Pitted Ware ceramics are small pits located on the shoulder and rim of the vessel (Figure 3). These pots, along with a similar marine subsistence orientation, site coastal location and tool kit, characterise sites found in east, west and south Sweden, east Denmark, south Norway and the islands in the Baltic Sea (PapmehlDufay 2006:32-45).

\section{Methodology}

Archaeologists study prehistoric material by grouping, separating and simplifying different types of data. The interpretation of past material culture is often based on analogy, and it is important to examine how analogies are employed in each case. One way of analysing archaeological data is by the use of statistical methods. In this study, a descriptive statistical method, the chi-squared test was applied to faunal assemblages from Pitted Ware sites, along with qualitative observations of their association with human skeletal remains. A discussion about the age of the sites follows, but all of the analysed samples are from Pitted Ware sites on Gotland, which are considered to comprise a single cultural entity, and which experienced similar environmental conditions during the Middle Neolithic.

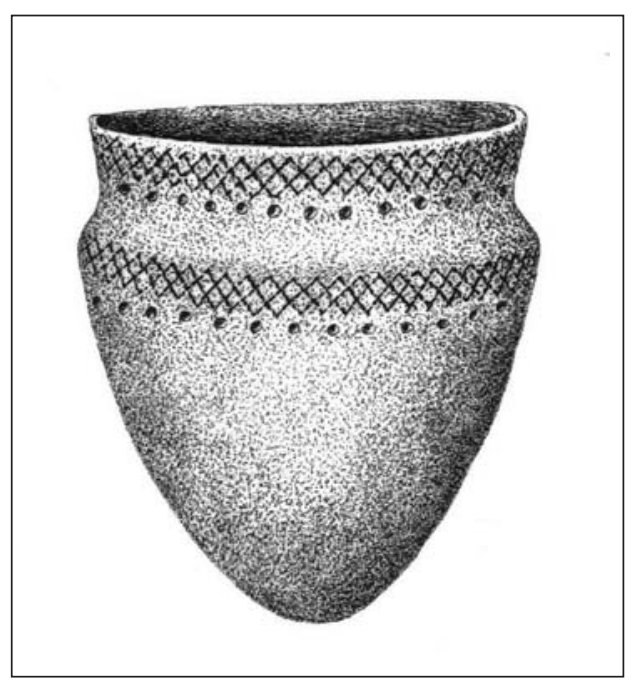

Figure 3. Typical Pitted Ware pot (drawing by Sven Österholm).
When studying prehistoric bone remains from occupation sites there is a tendency to regard differences in assemblage composition as the result of chronological and environmental factors. It is suggested, for instance, that during the Late Mesolithic and Early Neolithic, people went from a marine diet to a terrestrial diet because of an environmental change. The analysis of skeletal remains in megalith graves on Gotland and Öland supports this shift in particular instances (Lindqvist and Possnert 1997:48). Taking several cases of skeletal remains into account, however, the isotope evidence for prehistoric diet shows substantial variation (Papmehl-Dufay 2006:133). The same variation is also seen in a comparison of the animal bones from four Pitted Ware sites on Gotland, where the ratio of marine animals to terrestrial mammals and the contribution of both to the prehistoric diet has been examined (Storå 2001:Table 2). These differences might result from the cultural views about the use of animals by 
different Pitted Ware groups. Analogies drawn from traditional societies show that animals are important sources of food, yet they frequently have a significant role in a belief system (LéviStrauss 1969, 1971). It is suggested, then, that the variability in the bone remains from Pitted Ware sites might reflect the different ideologies and belief systems of Pitted Ware groups, and the remains are worthy, therefore, of a comparative analysis.

\section{Comparative studies of faunal bone remains from Pitted Ware sites on Gotland}

During the Middle and Late Neolithic phase (c. 5300-4250 BP), several large coastal settlements emerged on Gotland. Human skeletal remains from such sites have been dated to c. 4200-3700 BP, and seal bone from the sites has been dated to 4800-4350 BP. Additional dates from these sites include a pig bone dated to $4100 \mathrm{BP}$, while two dates on hedgehog bone have a span of c. 4400-4000 BP (Possnert 2002:171). The recovered bone material suggests that marine subsistence, especially the hunting of seals, was of great importance, but there was also husbandry of semi-domesticated pig (Sus scrofa), cattle (Bos taurus) and sheep/goat (Ovis aries/ Capra hircus) (Lindqvist and Possnert 1997:29). The need for pasture to feed cattle and sheep/ goats might have been accommodated by vegetation clearing and the expansion of pastoral areas near settlements. Sedentary occupation in Pitted Ware settlements is suggested from the presence of domestic structures and extensive cemeteries (Österholm 1989).

During the Middle Neolithic on Gotland, Österholm (1989) suggests there were 13 coastal settlements. One inland site is suggested to have been utilised during earlier settlement, but during the Pitted Ware phase it was used as a resource procurement area, rather than as a permanent residential site. The coastal sites were also likely to have been utilised previously, since many of them have some funnel-beaker pottery in the earliest layers (Österholm 1989).

Several of the largest Pitted Ware sites have been subject to archaeological investigation. The grave field at Västerbjers on the east side of Gotland (Figure 2) was excavated because it was being destroyed by gravel and sand quarrying (Stenberger et al. 1943). The cemetery remains were analysed (Stenberger et al. 1943; Janzon 1974; Eriksson 2004), but the settlement itself was not systematically excavated nor reported in detail. The most extensively excavated Pitted Ware site is Ajvide on the southwest of Gotland (Figure 2) (Österholm 1989; Burenhult 1997, 2002). Material from this site has not been incorporated in the statistical analysis, although the Ajvide bone remains are discussed below (Lindqvist and Possnert 1997).

\section{Faunal remains from Pitted Ware sites}

The bone database consisted of identified faunal bone remains recovered from five Pitted Ware sites: Hemmor (Hedell 1921), Visby (Wallin and Eriksson 1985), Ire (Landin 1981; Hegert 1982), Västerbjärs and Gullrum (Ekman 1974). The bone remains were recovered from different-sized excavation units, using different recovery techniques, but they represent the full range of Pitted Ware sites on Gotland. The statistical analysis of the faunal remains with the chisquared method was carried out in two parts. The first comparison examined the percentile share of the remains from four animal groups in each site: (1) pig; (2) other domesticated animals (sheep/goat, cattle and dog); (3) seals; (4) other wild animals. The second analysis compared the percentile share of domesticated (groups 1 and 2) and wild (groups 3 and 4) animal remains (Wallin and Martinsson-Wallin 1992:9-16).

The results of the analysis are shown in Figure 4 and Table 1. The composition of the analysed samples from Hemmor and Västerbjers sites on the east side of Gotland is similar, 
with both high in pig and domesticated-animal remains (groups 1 and 2). The bone samples from Visby and Gullrum on the west side of the island are also similar, and they have a higher proportion of wild animals. The fifth bone sample from the site of Ire in the north of Gotland is significantly different from the other four sites (Wallin and Martinsson-Wallin 1992:10-16), as it has a very high proportion of remains from wild animals (mainly seals), compared with domestic animals (Wallin and Martinsson-Wallin 1992:16).

There are also substantial differences between the composition of fauna at the Ajvide site and several Pitted Ware sites suggested by Lindqvist and Possnert (1997:49-50) to be contemporaneous. Over the course of settlement at Ajvide, there was a change from the utilisation of wild animals early on, to an increasing reliance on domesticated animals. However, compared with other Gotland sites (Table 1) considered contemporaraneous, there are still significant inter-site differences in the archaeofauna.

Since the faunal samples differed between sites in the type and the quality of recovery techniques, it was important to determine whether other sorts of archaeological data also displayed significant differences. A craniometric study of discrete traits was carried out on human remains from six Pitted Ware sites on Gotland by Sjøvold (1974). The analysis demonstrated a rather homogeneous 'Pitted Ware' population, but there was a statistically significant difference between the groups from Visby in the west and Västerbjers in the east (Sjøvold 1974:201). Another inter-group difference was that females from the Ire site had a significantly higher stature than females from other sites. The males from Ire also differed in size from males at the other sites, but this difference was not statistically significant.

Animal burials and animal parts in Pitted Ware graves have also been studied. It is clear that parts of pigs (mainly tusks and mandibles) were a frequent grave good that accompanied human burials at Ire (Table 1) (Janzon 1974:262-290), but these elements were uncommon in the bone remains from the habitation site. Seal teeth, used as ornaments, were a common grave good, and animals such as the hedgehog, especially hedgehog mandibles, and parts of exotic animals, such as beaver teeth and elk antler, were also regular grave goods (Janzon 1974). Parts of long bones from various sea birds were common in some graves, and have been interpreted as

Table 1. Statistical analysis of animal-bone samples from five Pitted Ware sites on Gotland. The compared sites and their chisquared values are listed, along with the significance value for each inter-site association.

\begin{tabular}{llll}
\hline Site comparison & chi-squared & significance & similarity/difference \\
\hline 1 Hemmor/Gullrum & 16.45 & 0.000 & significant difference \\
2 Hemmor/Visby & 12.26 & 0.000 & significant difference \\
3 Hemmor/lre & 118.68 & 0.000 & significant difference \\
4 Hemmor/Västerbjers & 0.046 & 0.831 & significant similarity \\
5 Visby//re & 61.28 & 0.000 & significant difference \\
6 Visby/Västerbjers & 12.26 & 0.000 & significant difference \\
7 Visby/Gullrum & 0.34 & 0.556 & significant similarity \\
8 Ire/Västerbjers & 112.51 & 0.000 & significant difference \\
9 lre/Gullrum & 58.68 & 0.000 & significant difference \\
10 Västerbjers/Gullrum & 16.45 & 0.000 & significant difference \\
\hline
\end{tabular}


whistles. A comparative analysis of all of the animal remains found in graves from Pitted Ware sites would be useful, but at the Hemmor and Gullrum sites, only a few skeletal remains and grave goods have been recovered (Janzon 1974:257-260).

\section{Discussion}

Site chronology and environmental variation

A clear difference can be seen between the faunal remains from sites on the east of Gotland and those from the two west-coast sites, but the main difference is between the Ire site in the north and the sites of Gullrum and Hemmor in the south (Figure 2). What is the reason for the inter-site variability in the faunal remains? The variation might be interpreted, for instance, as a difference in archaeological sampling methods, environmental variation, chronological difference in site age, or the result of different cultural views about animals among Pitted Ware groups.

Lindqvist and Possnert (1997:34) criticised the bone samples discussed above - which were first examined by Wallin and Martinsson-Wallin (1992) - and argued that the Pitted Ware sites were not contemporary with one another and that different recovery procedures had caused the inter-site differences in the fauna. They suggest the Middle Neolithic should be divided into two phases: Middle Neolithic A (MNA) from c. 5250 to 4750 BP, and Middle Neolithic B (MNB) from 4750 to 4250 BP. Lindqvist and Possnert (1997) base this chronology on differences in pottery style, with MNA characterised by the Säter/Fagervik style III pottery, which equates with the Hemmor/Gullrum phase on Gotland, and the MNB characterised by Säter/Fagervik IV pottery, which equates with the Visby/Ire/Västerbjärs stage pottery (Lindqvist and Possnert 1997:33). However, radiocarbon dates from Pitted Ware sites on Gotland (Papmehl-Dufay 2006:114) demonstrate that graves from the Västerbjers stage, interpreted as MNB by Lindquist and Possnert (1997), are actually contemporary with the Hemmor/Gullrum stage, interpreted by them as from MNA.

Further, several studies of Pitted Ware ceramics support the view that variability in Säter/Fagervik pottery styles may be related to vessel function (i.e. utilitarian, special function) and are not as chronologically defined as Lindqvist and Possnert (1997) suggest (e.g. Löfstrand 1974; Segerberg et al. 1991; Glørstad 1996; Kjellberg and Ytterberg 1996). In the future, the detailed intra-site analysis of fauna and ceramic remains should help to clarify this issue. Such a study was started at the Hemmor site in 1991, but heavy disruption of the site by ploughing meant that fine-grained faunal data could not be recovered (Hedemark et al. 2000).

At the intensively examined site of Ajvide (Lindqvist 1997; Lindqvist and Possnert 1997; Storå 2001; Burenhult 2002), significant variation in the distribution of faunal remains has been recorded, and is unlikely to be due solely to chronological factors,

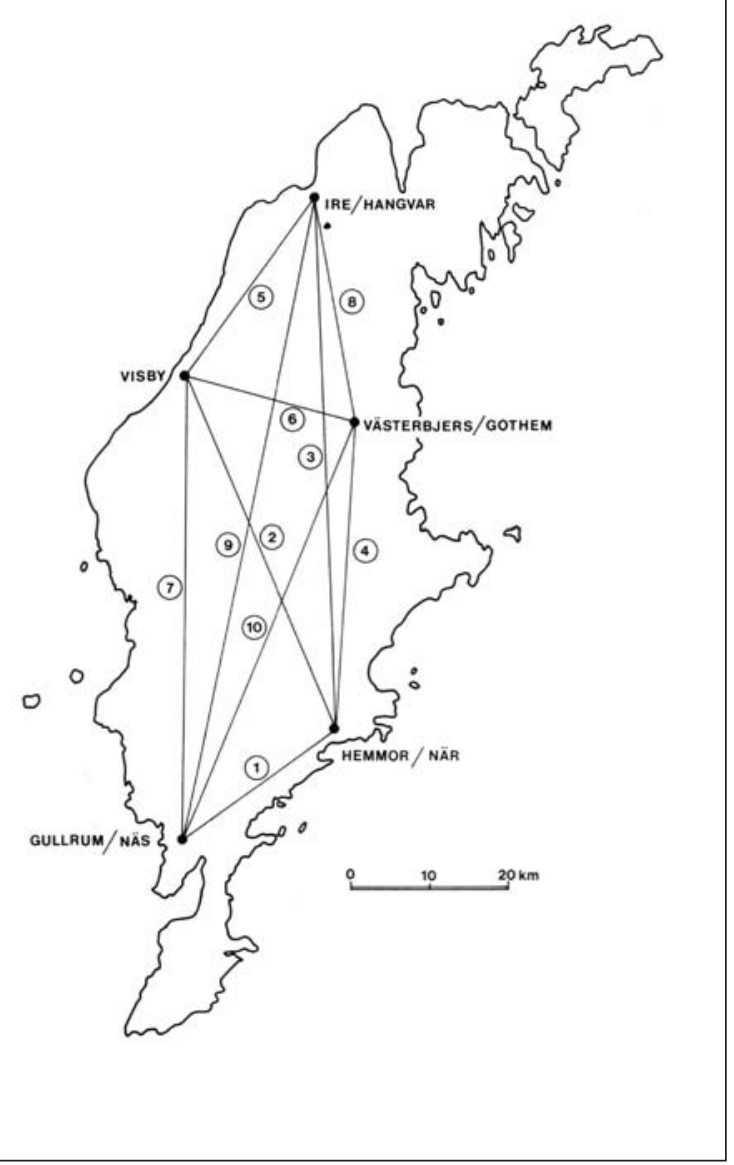

Figure 4. Analysis of the association between fauna from five Pitted Ware sites. 
although some change in animal use over time is apparent. As mentioned previously, Ajvide shows a shift from seal and sea-mammal hunting early on, to an increasing reliance on domesticated animals. A similar trend is also apparent at Hemmor, which has large amounts of fish bone in the basal levels of the site compared with the upper levels. As there is no stratigraphic evidence for a Litorina (brackish) transgression at Hemmor that would impact the range and abundance of marine species, it has been argued that there was a subsistence shift during occupation of the site (Wallin and Martinsson-Wallin 1992, 1993; Hedemark et al. 2000).

From an environmental perspective, some locations on Gotland were clearly more attractive for seals and fish, and Pitted Ware sites in such places might be expected to contain a greater proportion of marine foods (Storå 2001:7). Studies of seal and pig remains from Ajvide suggest resource scheduling, with pigs slaughtered from early autumn to mid-winter and seals (especially harp seals) hunted in late autumn and early winter (Rowley-Conway and Storå 1997). Gotland Island comprises a relatively small land area within the same climate zone, and Pitted Ware sites were all situated on the sea shore. Ethnohistorical accounts of Gotland suggest that seal hunting could be carried out all around the Gotland coast and on the nearby smaller islands (Säve 1867; Lithberg 1914:118; Linnaeus 1977; Wallin and Sten 2007). However, there is a marked environmental difference on Gotland, which has a high coast on the west and northwest, which may have reduced the amount of marine resources able to be taken in these areas.

The possibility that environmental variation is the cause of faunal variation needs to be investigated further, but the suggestion of Lindqvist and Possnert (1997:34) that winters would have been more severe in the north of Gotland, and that pigs could not cope with the cold conditions does not appear to be likely. Lindqvist and Possnert (1997) also remark that pig bones do not occur in Neolithic sites on Alland Islands further to the north in the Baltic Sea (Figure 1). Recent excavations at the Pitted Ware site of Jettböle on Åland and the analysis of archaeofauna from other Pitted Ware sites in the region demonstrate the presence of pig and other domesticated animals (Stora 2000). Analysis of diet from the study of human remains from Västerbjers and Öland indicates significant variation in subsistence during the Middle Neolithic, consistent with a mixed marine-hunting-farming subsistence economy (Eriksson 2004; Papmehl-Dufay 2006). Overall, while Pitted Ware groups emphasised marine foods, it is clear that domestic animals and vegetable foods were also being utilised.

\section{Animals with special meaning}

In modern and traditional societies the death and burial of an individual is a significant event for a community (Van Gennep 1981). The occurrence of entire-animal burials and parts of animals in Pitted Ware graves suggests these animals had special meaning to the people who carried out the burial ceremony. Using information from traditional cultures, Van Gennep (1981) and Turner (1969) describe death as a dangerous liminal stage where different rituals are used to secure the spirit of the dead and to make sure that it travels to the right place. Animal remains are often associated with death activity, sacrificed to guide/accompany the spirit of the dead, used for feasting, and because particular animals are significant in a community belief system, and symbolise clan/group affiliation. They are also associated with magic and the transformation from human to animal and animal to human, as well as creatures that are part-human and part-animal. These beliefs might be represented in a clay figurine found at the Pitted Ware site of Jettböle on Åland that appears to depict a human with a bird's head (Figure 5). The most common animal remains found in Pitted Ware graves are the remains of pigs (particularly tusks, mandibles and trotters), beaver (incisors), hedgehog (mandibles and spines), seals (teeth), sea bird (long bones), deer (antler), and teeth from cattle and other domestic mammals (Janzon 
1974). A common association is to have teeth and mandibles from the locally available seal and pig, and teeth and antler from animals foreign to Gotland, such as the beaver and elk. Many of the artefacts found in the graves, like harpoons and awls, are commonly made from pig bone.

It is worth considering that the type and age of animals associated with Pitted Ware burials might be related to the status of an individual, but the faunal remains could also signify the group/clan affiliation of an individual (Wallin and Eriksson 1985:16). Thus, differences in the bone remains from five Pitted Ware sites might reflect the community belief system, particularly the use of animals as group identifiers and symbols. In traditional societies it is common for animals to be seen as spiritual beings and ancestors of clan groups (Lévi-Strauss 1971). The relationship uniting the clan members and their totemic symbol is usually genealogically based, and is defined by complicated taboo regulations, including the use of particular animals in ritual and subsistence activity (Lauriston Sharp 1943:66-71; Lévi-Strauss 1969:56).

\section{Group identity and invisible borders}

Within any community, there exists unifying and dividing symbols that create borders and define social groups (Cohen 1992:12). Such borders are for the most part 'invisible' to archaeology, but by recognising that even quite similar groups were often distinguished from one another by their association with particular animals or plants, we can interrogate the faunal record for evidence of symbolic identity. Borders and divisions among groups or individuals are linked to symbols that express an individual's religion, status, gender and overall cultural identity (Cohen 1992:14).

Cohen (1992:19) described these cultural 'badges' thus: 'symbols of community are mental constructs: they provide people with the means to make meaning.' Using analogies from traditional societies, it is suggested that Neolithic societies were probably organised as tribes. The smallest unit within the tribe was probably the household, arranged as an extended family based on kinship. Several such groups probably formed a lineage group, which coalesced from a connection to a common ancestor. Several such lineage groups would comprise a clan, and while different lineages could claim they all were related, the relationship was not always clear because genealogical connections could be manipulated to strengthen ties to popular and strong clans.

The common ancestor might well have taken a mythological form, or been linked to a totem animal or plant. A number of clans probably made up a tribe that held a common territory (Sahlins 1968; Keesing 1981:227). Based on differences in the archaeofauna and consideration of the human

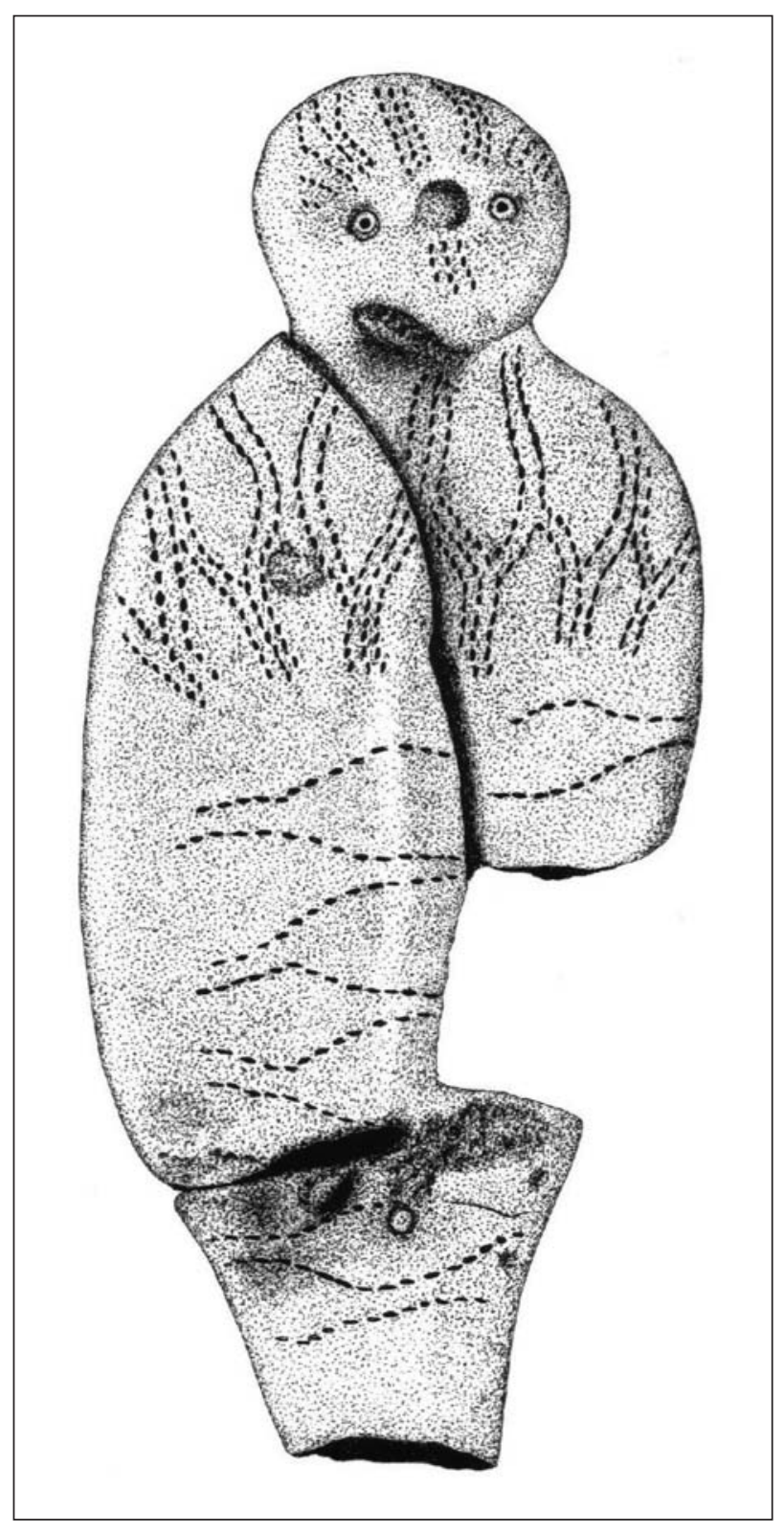

Figure 5. The Jettböle idol (drawing by Sven Österholm). 
skeletal remains and grave goods, an interpretation suggested here is that Gotland was divided into three major clan groups making up a Pitted Ware 'Gotland tribe'. There are notable differences in the composition of the faunal remains between Pitted Ware sites on the east and the west of Gotland, and there are also substantial differences between the faunal assemblage from Ire in the north and those of all other sites.

The difference between Hemmor/Västerbjers on the east of Gotland and Ire in the north might be explained by the hunting and consumption of seals and the avoidance of pigs at Ire. This contrasts with Hemmor/Västerbjers, where the consumption of pigs was favoured and seal consumption was avoided or restricted. At Visby and Gullrum on the west of Gotland, pigs and seals do not seem to have been viewed in a particular way, and other animals or plants might have been of greater ritual importance. The size and borders of clan areas were probably established using natural borders such as lakes and streams, and the location of neighbouring sites was probably also taken into consideration. A hypothetical division of clans and lineage groups based on faunal differences and the natural environment is given in Figure 6. The hypothesis outlined above from the differences identified in assemblages of faunal remains can be tested by additional isotope study of human bone from Pitted Ware sites, along with further chronological examination of Pitted Ware sites and a detailed intra-site analysis of faunal remains.

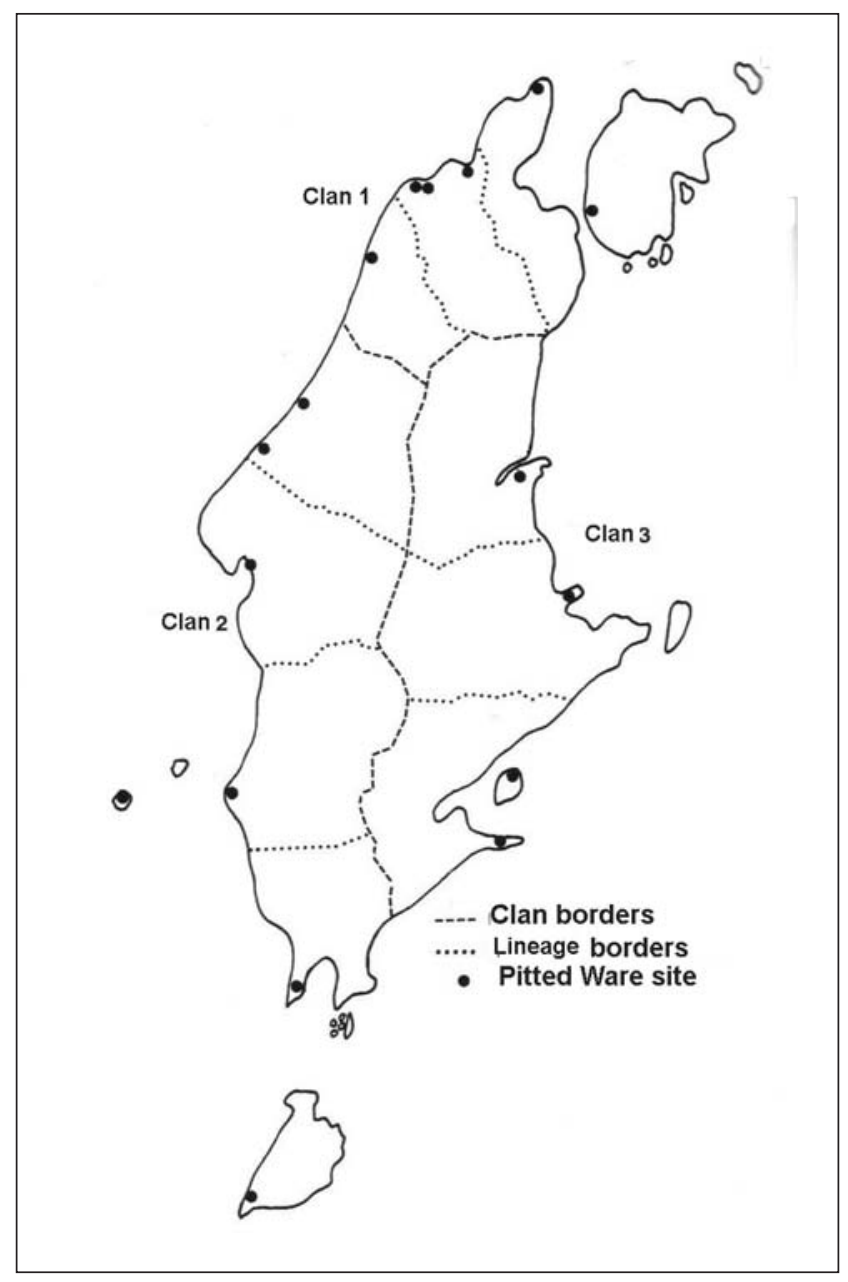

Figure 6. Hypothetical division of territorial units on Gotland during Middle Neolithic times based on differences in the faunal assemblages and natural landscape divisions. 


\section{Conclusion}

This paper identified significant differences among faunal remains from five Pitted Ware sites on Gotland. Differences in the fauna occur between sites on the east and west of the island as well as with the north of Gotland. These differences have also been noted in the study of human skeletal remains and are manifest in the grave goods found at some sites. Chronological and environmental variations have been reviewed, but such factors do not appear to account for all of the inter-site variability. How various Pitted Ware groups on Gotland might have viewed and incorporated different animals as symbols of community identity was also explored.

Various animals or parts of animals were intentionally buried with Pitted Ware dead. Since the inclusion of animal or animal parts in graves results from community activity, it shows that different animals had a particular status and role within a community group. An analysis of discrete skeletal traits and evidence for diet variability found in isotope studies of human remains is also consistent with inter-site variability. Taken together with natural landscape divisions, the evidence suggests the possibility of a Gotland Pitted Ware tribe consisting of three clan groups: one in the east, one in the west and one in the north. Each clan group is suggested to have been tied to a specific totem animal, which for the north clan may have been the pig, and for the east clan, the seal (the harp seal?). As mentioned previously, archaeology is often ill-equipped to identify how prehistoric social boundaries were constructed and maintained by symbols and behavioural restrictions. One common method of doing this among traditional societies is the use of animals in death rituals, feasting and subsistence. In the future, studies of archaeofauna might profit from a broader perspective that considers the social relationships between animals and people in the past.

\section{Acknowledgements}

This paper is based on analyses carried out in collaboration with Dr Paul Wallin in the early 1990s. I am most grateful to Paul that he has allowed me to use the data and for his support and discussions on Pitted Ware issues over the years. I also express my great appreciation for the support given to me by my good friend and colleague the late Dr. Inger Österholm and her husband Fil.Lic Sven Österholm, who both have been dedicated to the research on the Gotland Neolithic, and have at the same time introduced international perspectives and views gained from experimental archaeology.

\section{References}

Burenhult, G. (ed) 1997. Remote Sensing, vol. I. Theses and Papers in North-European Archaeology 13:a. Stockholm: Stockholm University.

Burenhult, G. (ed) 2002. Remote Sensing, vol. II. Theses and Papers in North-European Archaeology 13:a. Stockholm: Stockholm University.

Cohen, A. 1992. The Symbolic Construction of Community. London: Routledge.

Ekman J. 1974. Djurbensmaterialet från Stenålderslokalen Ire, Hangvar Sn. Gotland. In G. Janzon (ed.), Gotlands Mellanneolitiska Gravar, pp. 212-246. Studies in North-European Archaeology 6. Stockholm, Almqvist and Wiksell Stockholm.

Eriksson, G. 2003b. Part time farmers or hard-core sealers? Västerbjers studied by stable isotope analysis. Journal of Anthropological Archaeology 23:135-162. 
Glørstad H. 1996. Neolitiske Smuler. Små teoretiske og praktiske bidrag til debatten om neolitisk keramik og kronologi i Sør-Norge. Varia 33. Oslo: Universitetets Oldsaksamling

Hedell, L. 1921. Osteologisk analys frän Hemmor, När Sn, Gotland. Unpublished report, Stockholm,Vitterhetsakademin.

Hegert, A. 1982. Osteologisk analys av djurbensmaterial från stenåldersboplatsen Ire på Gotland. Unpublished thesis, Osteologi II. Osteologiska forskningslaboratoriet. Stockholms universitet, Solna.

Hedemark, Å., C. Samuelsson and N. Ytterberg 2000. Stenåldersboplatsen vid Hemmor i ny belysning. Gotländskt arkiv (2000):7-28.

Hodder, I. 1990. The Domestication of Europe. Cambridge: Blackwell.

Janzon, G. 1974. Gotlands mellanneolitiska gravar. Studies in North-European Archaeology 6.

Keesing, R.M. 1981. Cultural Anthropology. A Contemporary Perspective. New York: Rinehart and Winstone.

Kjellberg A. and N. Ytterberg 1996. Analys av Gropkeramik. Unpublished report, Department of Archaeology, Uppsala University.

Landin, M. 1981. Osteologiska bestämningar av materialet från stenåldersboplatsen Ire på Gotland. Unpublished thesis in Osteologi II. Osteologiska forskningslaboratioriet, Stockholms universitet, Solna.

Lauriston S.R. 1943. Notes on Northeast Australian Totemism. Studies in the Anthropology of Oceania and Asia 1943. Papers of the Peabody Museum of American Archaeology and Ethnology, Volume XX.

Lévi-Strauss, C. 1962. La Pensée sauvage. Paris: Plon.

Lévi-Strauss, C. 1963. Totemism. Boston: Beacon Press.

Lindqvist, C. 1997a. About the importance of fine-mesh sieving, stratigraphical and spatial studies for interpretation of faunal remains at Ajvide, Eksta parish, and other Neolithic dwelling sites on Gotland. In G. Burenhult (ed), Remote Sensing, vol. 1. Theses and Papers in North-European Archaeology 13:a:91-111. Stockholm, Stockholm University.

Lindqvist, C. and G. Possnert. 1997b. The subsistence economy and diet at Jakobs/Akvide, Eksta parish and other prehistoric dwellings and burial sites on Gotland in a long-term perspective. In G. Burenhult (ed), Remote Sensing, vol. 1. Theses and Papers in North-European Archaeology 13:a:29-90. Stockholm University.

Lindqvist, C. and G. Possnert. 1999. The First Seal hunter Families on Gotland, on the Mesolitich Occupation in the Stora Förvar Cave. Current Swedish Archaeology 7:65-87.

Linnaeus, C. 1977. Öländska och gotländska resa förrättad år 1741. London: Wahlström and Widstrand.

Lithberg, N. 1914. Gotlands stenålder. Stockholm: Jacob Bagges Söners AB.

Löfstrand, L. 1974. Yngre stenålders kustboplatser. Undersökningar vid Äs och studier i den gropkeramiska kulturens kronologi ich ekologi. AUN 1. Uppsala.

Martinsson, H. 1986. Ålands stenålder. kronologi, komparativa studier samt försök till en bosättningsmodell. Unpublished BA thesis, Stockholm University.

Nihlén J. 1927. Gotlands stenåldersboplatser. Kungl. Vitterhets Historie och Antikvitetsakademiens Handlingar 36:3.

Österholm, I. 1989. Bosättningsmönster på Gotland under stenåldern. En analys av fysisk miljö, ekonomi och social struktur. Theses and Papers in Archaeology 3. Visby: Gotland University.

Österholm, I. 1999. Stenåldern på Gotland. In G. Burenhult (ed), Arkeologi i Norden 1, pp. 340-341. Stockholm: Natur och kultur.

Papmehl-Dufay. L. 2006. Shaping an identity. Pitted Ware pottery and potters in southeast Sweden. Theses and papers in Scientific Archaeology. Stockholm: Stockholm Univeristy.

Possnert, G. 2002. Stable and radiometric carbon results from Ajvide. In G. Burenhult (ed), Remote Sensing, vol. 1. Theses and Papers in North-European Archaeology 13:a:169-172. Stockholm: Stockholm University.

Rowley-Conway, P. 1983. Sedentary hunters: the Ertebølle example. In G. Bailey (ed), Hunter gatherers in prehistory. A European perspective, pp. 111.126. New York: Cambridge University. 
Rowley-Conway, P. and J. Storå 1997. Pitted Ware seals and pigs from Ajvide, Gotland: Methods of study and first results. In G. Burenhult (ed), Remote Sensing, vol. 1. Theses and Papers in NorthEuropean Archaeology 13:a:113-125. Stockholm: Stockholm University.

Sahlins, M. 1968. Tribesmen. New Jersey: Engelwood Cliffs, Prentice-Hall, Inc.

Segerberg, A., G. Possnert, B. Arrenius and K. Lidén 1991. Ceramic chronology in view of 14C datings. Laborativ arkeologi 5:83-91.

Sjøvold, T. 1974. Some Aspects of Physical Anthropology on Gotland During Middle Neolithic Times. In G. Janzon (ed), Gotlands mellanneolitiska gravar. Stockholm, Studies in North-European Archaeology 6.

Stenberger, M., E. Dahr und H. Munthe 1943. Das Grabfeld von Västerbjers auf Gotland. Stockholm: Kungl. Vitterh. Hist. och Anitkv. Akademien.

Storå, J. 2000. Sealing and animal husbandry in the Ålandic Middle and late Neolithic. Fennoscandia archaeology XVII:57-81.

Storå, J. 2001. Seal Hunting on Ajvide. A Taphonomic Study of Seal Remains from a Pitted Ware culture Site on Gotland. Reading Bones. Stone Age Hunters and Seals in the Baltic. Stockholm Studies in Archaeology 21.

Svensson, N.O. 1989. Late Weichselian and Early Holocene shore displacement in Central Baltic, based on stratigraphical and morphological records from Eastern Småland and Gotland, Sweden. Lundqua Thesis 25, Department of Quarternary Geology, Lund.

Turner, V. 1969. The ritual process. Structure and Anti-structure. Chicago: Aldine Publishing Company.

Van Gennep, A. 1981. Les rites de passage. Etude systématique des rites. Paris: Picard.

Wallin, P. and T. Eriksson 1985. Osteologisk analys av djur-och människoben frän stenåldersboplatsen $i$ Visby på Gotland. Uppsats för Osteologi II. Osteologiska forskningslaboratoriet, Stockholms universitet, Solna.

Wallin, P. and H. Martinsson-Wallin 1992. Studier kring gropkeramisk identitet på Gotland. Gotländskt arkiv (1992):7-26.

Wallin, P. and H. Martinsson-Wallin 1993. Lokalkorologiska studier eller mönster med mening. Provundersökning av den gropkeramiska boplatsen Hemmor, När sn., Gotland del 2. Unpublished report, Länstyrelsen på Gotland.

Wallin, P. and H. Martinsson-Wallin 1997. Osteological analysis of skeletal remains from a megalith grave at Ansarve, Tofta parish, Gotland. In G. Burenhult (ed), Remote Sensing, vol. 1. Theses and Papers in North-European Archaeology 13:a:23-28. Stockholm: Stockholm University.

Wallin, P and S. Sten 2007. Säljakten på Gotland. Gotländskt arkiv (2007):23-40.

Wyszomirska, B. 1984. Figurplastic och gravskick hos Nord och Nordösteuropas neolitiska fångstkultur. Acta archeologica Lundensia 18.

Zvelebil, M. and P. Rowley-Conway 1984. Transition to farming in northern Europe: a hunter-gatherer perspective. Norwegian Archaeological Review 17:104-128. 